\title{
POTENSI BIOSORBEN TANDAN KOSONG KELAPA SAWIT (TKKS) DALAM RECOVERY LIMBAH FENOL
}

\author{
Mamay Maslahat*, Richson P. Hutagaol dan Shanti Lestari \\ PS Kimia FMIPA Universitas Nusa Bangsa \\ Jl. K. H. Sholeh Iskandar, Cimanggu, Tanah Sareal - Bogor 16166 \\ *email : maykulsum@yahoo.co.id
}

\begin{abstract}
Potential Biosorben of Oil Palm of Empty Bunch (TKKS) for Recovery of Phenol Waste

The palm oil industry is one of the strategic industries engaged in agro - based industry are widely grown in tropical countries such as Indonesia, Malaysia and Thailand. Oil palm plantations produce solid waste, one of them in the form of empty fruit Bunche (TKKS). Utilization of the TKKS is still not optimal. Oil TKKS contains chemical compounds in the form of cellulose that can be used as a biosorben. TKKS Biosorben can be used for recovery phenolic compounds waste. Phenol is one of the components in the waste water that is very dangerous, because the toxic and corrosive to the skin as well as carcinogenic, therefore phenol classified as hazardous material (B3). The research aimed to determine the optimum absorption of phenolle waste by TKKS biosorben, determination of adsorption isotherm equation and comparing the effectiveness of the modified TKKS (BTB) biosorben and without modification (BTM). The optimum conditions of sorption included contact time, biosorben weight, the effect of $\mathrm{pH}$ and concentration of phenol. The results showed that the optimum conditions BTM adsorption at 120 minutes, biosorben weighs 1 gram and $\mathrm{pH}$ 7. BTB optimum conditions was $10 \mathrm{~min}$ adsorption time, biosorben weights 0.5 grams and $p H 5$. Adsorption capacity $(Q)$ at the optimum conditions BTM and BTB, respectively, 84.4081 and $502.724 \mathrm{mg} / \mathrm{g}$ biosorben, this showed that the adsorption capacity of phenol by modified TKKS biosorben provided greater results. Adsorption of phenol solution by BTM and BTB follow Langmuir isotherm equation.
\end{abstract}

Key word : biosorben, TKKS, phenol, adsorption, Langmuir isotherm

\begin{abstract}
ABSTRAK
Industri kelapa sawit merupakan salah satu industri strategis yang bergerak pada sektor pertanian (agrobased industry) yang banyak berkembang di negara-negara tropis seperti Indonesia, Malaysia dan Thailand. Perkebunan kelapa sawit menghasilkan limbah padat, salah satunya berupa tandan kosong. Pemanfaatan limbah tandan kosong saat ini masih belum maksimal. Tandan Kosong Kelapa Sawit (TKKS) mengandung senyawa kimia berupa selulosa sehingga limbah TKKS dapat dimanfaatkan sebagai biosorben. Biosorben TKKS dapat digunakan untuk pengelolaan limbah senyawa fenol. Fenol merupakan salah satu komponen dalam air limbah yang sangat berbahaya, karena beracun dan bersifat korosif terhadap kulit serta karsinogenik, oleh karena itu fenol digolongkan sebagai bahan beracun dan berbahaya (B3). Tujuan penelitian adalah untuk mengetahui kondisi optimum proses sorpsi limbah fenol oleh biosorben asal TKKS, penentuan persamaan isotherm adsorpsi, serta membandingkan efektifitas biosorben TKKS yang dimodifikasi (BTB) dengan biosorben TKKS tanpa modifikasi (BTM). Kondisi optimum sorpsi meliputi waktu kontak, bobot biosorben, pengaruh $\mathrm{pH}$ dan konsentrasi fenol. Hasil penelitian menunjukan bahwa kondisi optimum BTM pada waktu adsorpsi 120 menit, bobot biosorben 1 gram, dan $\mathrm{pH}$ 7. Kondisi optimum BTB adalah waktu adsorpsi 10 menit, bobot biosorben 0,5 gram, dan pH 5. Kapasitas adsorpsi (Q) pada kondisi optimum BTM dan BTB berturut-turut adalah 84,4081 dan $502,724 \mu \mathrm{g} / \mathrm{g}$ biosorben, hal ini menunjukan bahwa kapasitas adsorpsi fenol oleh biosorben TKKS yang dimodifikasi memberikan hasil yang lebih besar. Adsorpsi larutan fenol oleh BTM dan BTB mengikuti persamaan isoterm Langmuir.
\end{abstract}

Kata Kunci : Biosorben, TKKS, Fenol, Adsorpsi, isotherm Langmuir 


\section{PENDAHULUAN}

Tandan Kosong Kelapa Sawit (TKKS) merupakan limbah terbesar dari pabrik kelapa sawit, yaitu sekitar 23\% dari jumlah tandan buah segar (TBS) sehingga ketersediannya berlimpah setiap tahunnya. Komponen utama limbah pada kelapa sawit ialah selulosa dan lignin, sehingga limbah ini disebut sebagai limbah lignoselulosa (Darnoko, 1993). Selulosa adalah senyawa karbon yang terdiri lebih dari 1000 unit glukosa yang terikat oleh ikatan beta 1,4 glikosida dan dapat didekomposisi oleh berbagai organisme selulolitik menjadi senyawa $\mathrm{C}$ sederhana. Sedangkan lignin merupakan komponen limbah TKKS yang relatif sulit didegradasi. Senyawa ini merupakan polimer struktural yang berasosiasi dengan selulosa dan hemiselulosa.

Dilihat dari strukturnya, selulosa mempunyai potensi yang cukup besar untuk dijadikan sebagai penjerap karena gugus $\mathrm{OH}$ yang terikat dapat berinteraksi dengan komponen adsorbat. Adanya gugus $\mathrm{OH}$, pada selulosa menyebabkan terjadinya sifat polar pada adsorben tersebut. Dengan demikian selulosa lebih kuat menjerap zat yang bersifat polar dari pada zat yang kurang polar (Yantri,1998).

Di sisi lain keberadaan limbah fenol dari hasil limbah industri juga cukup menyita banyak perhatian. Limbah senyawa fenol dihasilkan dari limbah cair industri mikroelektronik, industri minyak dan gas, tekstil, kertas, otomotif, dan pabrik bahan kimia. fiber-glass, pulp kertas, perekat, kayu lapis, farmasi, cat, tekstil, keramik, plastik, formaldehid dan sebagainya. senyawa fenol bila mencemari perairan dapat menimbulkan rasa dan bau tidak sedap dan pada konsentrasi nilai tertentu akan menyebabkan kematian organisma di perairan. Senyawa fenol dapat menimbulkan efek kronik bagi organisme dan menyebabkan kematian pada ikan pada konsentrasi yang sangat rendah, yakni $5-25 \mathrm{mg} / \mathrm{L}$ (Alva \& Peyton, 2003), fenol dapat mengalami bioakumulasi dan biomagnifikasi oleh organisme perairan (akuatik), fenol dapat masuk ke dalam tubuh melalui air minum dan makanan yang berasal dari organisme akuatik.

Polutan di daerah perairan, termasuk fenol dapat dihilangkan dengan beberapa teknik, di antaranya adalah adsorpsi. Adsorpsi adalah pemisahan suatu senyawa dari larutannya yang kemudian terdeposisi pada permukaan padatan, pada bidang kontak antara padatan dengan larutan, sedangkan desorpsi yaitu pelepasan senyawa dari padatan di mana senyawa terdeposisi atau menempel ke dalam larutannya (Watts, 1998). Biosorben didefinisikan sebagai bahan biologis yang digunakan dalam proses penjerapan pencemar dari suatu cairan, selanjutnya melalui proses desorpsi bahan ini dapat dibuang dan lebih ramah lingkungan

Jenis - jenis adsorpsi berdasarkan gaya tarik menarik antara adsorben dengan adsorbat, secara garis besar terbagi menjadi dua macam, yaitu kemisorpsi (adsorpsi secara kimia) dan fisisorpsi (adsorpsi secara fisika). Fisisorpsi terjadi karena adanya gaya Van der Waals atau gaya hidrogen. Interaksi ini merupakan interaksi yang lemah sehingga adsorbat tetap mampu bergerak pada permukaan adsorben dan mengakibatkan proses adsorpsi terjadi secara spontan dan reversibel. Kemisorpsi terjadi dengan pembentukan ikatan kimia (umumnya ikatan kovalen) dan cenderung mencari sisi-sisi yang memaksimumkan bilangan koordinasi substrat, baik adsorben maupun adsorbat. Hal ini menyebabkan adsorbat akan terlokalisasi pada permukaan adsorben sehingga kemisorpsi bersifat irreversibel (Anggaraningrum 1996).

Adsorpsi dapat dimodelkan dengan istilah isoterm yang merupakan fungsi konsentrasi zat terlarut yang terjerap pada padatan terhadap konsentrasi larutan. Persamaan yang biasa digunakan untuk menjelaskan data percobaan isoterm dikaji dan dikembangkan oleh Freundlich, Langmuir, dan Brunauer, Emmet, Teller (BET). 


\section{BAHAN DAN METODE}

Alat dan Bahan

Penelitian ini menggunakan berbagai macam jenis alat, yaitu Spektrofotometer VIS Genesys 20, Spektrofotometer Infra Merah, oven Memmert UL50, Neraca analitik, $\mathrm{pH}$ meter Eutech Instruments pH 510, seperangkat alat gelas seperti buret, pipet tetes, pipet volumetrik, corong pemisah, Erlenmeyer dan piala gelas, shiever ukuran 80-100 mesh. Bahan yang digunakan dalam penelitian ini yaitu, serbuk TKKS ukuran 80-100 mesh, $\mathrm{HCl}$ p.a, $\mathrm{NaOH}$ p.a, Fenil alkohol p.a, Kloroform p.a, 4aminoantipirin $2 \%$, Kalium Ferrisianida $8 \%$, Natrium Sulfat p.a, Ammonium Hidroksida.

\section{Metode}

Penelitian ini meliputi dua tahap yaitu tahap persiapan dan tahap penelitian. Tahap persiapan terdiri atas preparasi sampel tandan kosong kelapa sawit yang disebut biosorben tanpa modifikasi (BTM), diikuti analisis kadar air dan analisis gugus aktif dari biosorben dengan spektrofotometer IR. Setelah itu impregnasi menggunakan $\mathrm{NaOH}$ yang menghasilkan biosorben terimpregnasi basa (BTB), penentuan panjang gelombang maksimum dan kalibrasi fenol. Tahap penelitian terdiri dari penentuan kondisi optimum berupa waktu, bobot biosorben, $\mathrm{pH}$, serta konsentrasi fenol.

\section{Tahapan Persiapan}

\section{a. Preparasi Sampel Tandan Kosong Kelapa Sawit}

Limbah tandan kosong kelapa sawit dicuci dengan air mengalir dan aquades sampai bersih, setelah itu dikering di oven pada suhu $70^{\circ} \mathrm{C}$, dan digiling sampai berukuran 80- 100 mesh. Serbuk tandan kosong kelapa sawit ini selanjutnya disebut biosorben tanpa modifikasi (BTM). Biosorben ini kemudian dilihat sisi aktif dengan menggunakan spektrofotometer IR.

\section{b. Kadar Air Biosorben Tandan Kosong Kelapa Sawit}

Cawan petri kosong dikeringkan selama satu jam pada suhu $105^{\circ} \mathrm{C}$ dalam oven, lalu ditimbang bobotnya dengan teliti (W1), setelah didinginkan dalam eksikator. Sebanyak 1 g contoh uji ditimbang teliti (W2) di dalam cawan petri itu, lalu dikeringkan kembali pada suhu yang sama. Setelah tercapai bobot konstan (W3), kadar air dapat dihitung dengan persamaan berikut :

kadar $\operatorname{air}(\%)=1-\frac{W 3-W 1}{W 2} \times 100 \%$

\section{c. Biosorben Terimpregnasi Basa}

Sebanyak $100 \quad \mathrm{~g} \quad$ BTM ditambahkan $2 \mathrm{~L} \mathrm{NaOH} 0.1$ N. Campuran dikocok selama 20 menit sambil dipanaskan pada suhu $80^{\circ} \mathrm{C}$ kemudian disaring dan airnya dibuang. Setelah itu, dicuci dengan menggunakan air suling untuk menghilangkan kelebihan basa. Sampel dikeringkan dalam oven pada suhu $50^{\circ} \mathrm{C}$ selama 24 jam (Marshall \& Mitchell 1996). Sampel yang dihasilkan selanjutnya disebut biosorben terimpregnasi basa (BTB).

d. Penentuan Panjang Gelombang Maksimum dan Kalibrasi Fenol

Sederet labu ukur $50 \mathrm{~mL}$ disiapkan untuk membuat standar fenol. Larutan baku fenol (100 ppm) dipipet sebanyak 0 , $1,2,4,6,8$ dan $10 \mathrm{~mL}$ dimasukkan ke dalam labu ukur $50 \mathrm{ml}$ kemudian ditambahkan akuades sampai tanda tera. Pipet sebanyak $5 \mathrm{ml}$ masing - masing standar fenol kemudian dimasukkan kedalam gelas piala $200 \mathrm{ml}$, setelah itu tambahkan akuades sampai volume 100 ml. Tambahkan $1 \mathrm{ml} \mathrm{NH}_{4} \mathrm{Cl} 5 \%$, atur $\mathrm{pH}$ larutan sampai $\mathrm{pH} \quad 10 \pm 0.2$ dengan menambahkan $\mathrm{NH}_{4} \mathrm{OH} 1: 1$.

Larutan tersebut dipindahkan ke dalam corong pisah, dan dibilas dengan air sampai $3 \mathrm{x}$ bilasan. Tambahkan $0,3 \mathrm{ml}$ larutan 4-aminoantipirin 2\%, kocok 
sebentar dan tambahkan pula $0,3 \mathrm{ml}$ $\mathrm{K}_{3} \mathrm{Fe}(\mathrm{CN})_{6} \quad 8 \%$. Kocok kembali dan biarkan selama \pm 3 menit sampai terjadi perubahan warna (merah muda). Setelah terjadi perubahan warna, lalu ditambahkan $25 \mathrm{~mL}$ kloroform dikocok selama \pm 5 menit, setelah terjadi pemisahan campuran, corong pisah dikocok kembali 10 kali lalu dibiarkan campuran terpisah kembali. Setelah terjadi pemisahan, lapisan kloroform dipisahkan dan disaring dengan kertas saring yang berisi $\mathrm{Na}_{2} \mathrm{SO}_{4}$.

Dengan menggunakan ekstrak kloroform dari blangko, spektrofotometer Vis (Genesys 20) di nol kan, lalu absorbansi salah satu larutan diukur pada panjang gelombang $400 \mathrm{~nm}$ sampai 600 $\mathrm{nm}$ untuk mencari atau mendapatkan panjang gelombang maksimum. Kemudian masing - masing larutan diukur absorbansinya pada panjang gelombang maksimum tersebut untuk membuat kurva kalibrasi. Nilai absorbansi yang dihasilkan kemudian dibuat kurva standar, yakni absorbansi versus ppm fenol.

\section{Tahapan Penelitian}

\section{a. Penentuan Waktu Kontak Maksimum}

Sebanyak $0,5 \mathrm{~g}$ biorsorben BTM dan BTB dimasukkan ke dalam $25 \mathrm{ml}$ larutan fenol dengan konsentrasi $10 \mathrm{ppm}$, kemudian larutan dikocok dengan shaker kecepatan $125 \mathrm{rpm}$. Adsorpsi dilakukan dengan ragam waktu adsorpsi $0,15,30$, $45,60,120$, dan 240 menit pada $\mathrm{pH} 5,5$ (pH awal larutan fenol). Setelah itu campuran disaring dan absorbansi filtratnya diukur pada panjang gelombang dengan serapan maksimum untuk larutan fenol adalah $454 \mathrm{~nm}$. Waktu optimum ditentukan dengan menghitung kapasitas adsorpsi maksimum.

\section{b. Penentuan Kondisi Optimum Bobot Biosorben}

Variasi bobot biosorben BTM dan BTB yang digunakan adalah 0,$5 ; 1,0 ; 2,0$ dan 4 gram. Masing - masing dimasukkan ke dalam $50 \mathrm{ml}$ larutan fenol $10 \mathrm{ppm}$ kemudian dikocok dengan shaker.
Adsorpsi dilakukan pada waktu optimum dan $\mathrm{pH}$ 5,5. Campuran dikocok pada waktu optimum adsorpsi. Campuran disaring dan absorbansi filtratnya diukur pada panjang gelombang $454 \mathrm{~nm}$.

Perhitungan :

$Q=\frac{V(C o-C a)}{m}$

$\mathrm{Q}=$ Kapasitas adsorpsi per bobot biosorben ( $\mu \mathrm{g} / \mathrm{gram}$ biosorben)

$\mathrm{V}=$ Volume larutan $(\mathrm{ml})$

$\mathrm{Co}=$ Konsentrasi awal (ppm)

$\mathrm{Ca}=$ Konsentrasi akhir $(\mathrm{ppm})$

$\mathrm{m}=$ Bobot biosoren (gram)

c. Pengaruh $\mathrm{pH}$ pada Adsorpsi

Bobot optimum biosorben BTM dan BTB yang diperoleh ditambahkan ke dalam Erlenmeyer yang berisi $50 \mathrm{ml}$ larutan fenol 10 ppm dengan $\mathrm{pH} 3,0 ; 5,0$; 7,0 dan 9;0.

Campuran dikocok pada waktu optimum dan bobot optimum, kemudian disaring dan diukur absorbansinya pada panjang gelombang $454 \mathrm{~nm}$.

\section{d. Penentuan Konsentrasi Fenol (sebagai adsorbat)}

Erlenmeyer yang berisi bobot optimum biosorben BTM dan BTB dimasukkan ke dalam $50 \mathrm{ml}$ larutan fenol pada konsentrasi $0,2,4,6,8$, dan $10 \mathrm{ppm}$ pada kondisi $\mathrm{pH}$ dan waktu optimum. Setelah itu campuran disaring dan diukur absorbansinya pada panjang gelombang $454 \mathrm{~nm}$.

\section{e. Penentuan Kadar Fenol dalam Filtrat (Fenol dalam kesetimbangan)}

Filtrat hasil dari proses adsorpsi diambil masing-masing $5 \mathrm{~mL}$ lalu dimasukkan ke dalam gelas kimia $200 \mathrm{~mL}$ ditambahkan dengan akuadest sampai 100 $\mathrm{mL}$, akuades sebanyak $5 \mathrm{~mL}$ disediakan juga sebagai blanko, kemudian masing- 
masing larutan ditambahkan $1 \mathrm{~mL} \mathrm{NH} \mathrm{NH}_{4} \mathrm{Cl}$ 5\% dan diatur pH-nya antara 9,8 - 10,2 dengan penambahan $\mathrm{NH} 4 \mathrm{OH} 1: 1$.

Campuran dipindahkan ke dalam corong pisah dan ditambahkan $0,3 \mathrm{~mL}$ larutan 4-aminoantipirin $2 \%$ dan $0,3 \mathrm{~mL}$ larutan kalium ferrisianida $8 \%$, lalu dikocok dengan segera, lalu campuran didiamkan sampai terjadi pewarnaan (merah muda). Setelah terjadi perubahan warna, ditambahkan $25 \mathrm{~mL}$ kloroform, dikocok selama \pm 5 menit, kemudian setelah terjadi pemisahan, corong pisah dikocok kembali 10 kali lalu dibiarkan campuran terpisah. Setelah terjadi pemisahan, lapisan kloroform dipisahkan dan disaring dengan kertas saring yang berisi $\mathrm{Na}_{2} \mathrm{SO}_{4}$.

Spektrofotometer Vis (Genesys 20) di nol kan pada $\lambda$ maksimum hasil dari pengukuran pada tahap persiapan dengan menggunakan ekstrak kloroform dari blangko. Absorbansi dari ekstrak masingmasing sampel diukur pada $\lambda$ maksimum, kemudian besarnya konsentrasi fenol diperoleh dari persamaan pada kurva standar.

Perhitungan :

$\operatorname{ppm~Fenol}_{\text {(setimbang) }}=\frac{A}{\text { Slope }} \times f p$

$\mathrm{A}=$ Absorbansi
$\mathrm{Fp}=$ faktor pengenceran

\section{HASIL DAN PEMBAHASAN}

\section{Preparasi Sampel Tandan Kosong Kelapa Sawit}

Limbah tandan kosong kelapa sawit (TKKS) yang digunakan dalam penelitian berasal dari PT Perkebunan Nasional Kelapa Sawit Cigudeg dan PT Perkebunan Nasional Kelapa Sawit VI Cimulang. Limbah TKKS yang digunakan adalah limbah yang masih segar dan belum ditumbuhi jamur. Limbah tkks yang digunakan sebagai biosorben digiling terlebih dahulu untuk mendapatkan ukuran partikel yang ditetapkan (80-100 mesh). Penentuan ukuran partikel dilakukan agar sampel yang digunakan seragam. Karena dalam proses sorpsi padatan-cairan ukuran partikel sangat mempengaruhi kapasitas adsorpsi. Ukuran pori dan luas permukaan adsorben merupakan hal yang sangat penting dalam adsorpsi (Lynch, 1990). Perbesaran luas permukaan adsorben dapat dilakukan dengan pengecilan partikelnya. Semakin kecil ukuran partikel akan memperluas permukaan biosorben sehingga ketersediaan sisi aktif biosorben akan meningkat. Bertambahnya sisi-sisi aktif dari permukaan biosorben dapat memungkinkan adsorpsi terjadi di lebih banyak tempat pada permukaan biosorben. Jumlah permukaan biosorben yang meningkat akan meningkatkan jumlah adsorbat yang terjerap.

\section{Sisi Aktif Biosorben TKKS}

Limbah tkks yang sudah dihaluskan dilihat sisi aktifnya dengan menggunakan spektrofotometer Infra Merah, puncak-puncak spektogram infra merah TKKS dapat dilihat pada Gambar 1. Hasil interpretasi terhadap spektrum infra merah tandan kosong kelapa sawit memperlihatkan adanya puncak serapan pada daerah $3400-3300 \mathrm{~cm}^{-1}$ menunjukkan adanya gugus hidroksil. Pada daerah 3000$3300 \mathrm{~cm}^{-1}$ terjadi penyerapan yang kuat yang menunjukkan adanya regang $\mathrm{C}-\mathrm{H}$ aromatik, didukung dengan adanya serapan pada daerah 1650-1500 $\mathrm{cm}^{-1}$ yang merupakan spektrum pendukung untuk mengidentifikasikan senyawa aromatik, puncak serapan juga ditunjukan pada daerah 850-650 $\mathrm{cm}^{-1}$ yang merupakan regang Ar-H. Serapan yang cukup kuat juga ditunjukan pada daerah 1900-1650 $\mathrm{cm}^{-1}$ yang merupakan regangan aldehid. Gugus $\mathrm{OH}$ dapat diidentifikasikan sebagai senyawa polisakarida seperti selulosa yang merupakan susunan terbesar dari tkks. Terdapat senyawa aromatik yang kemungkinan besar menunjukkan adanya senyawa lignin.

Dua jenis biosorben yang digunakan dalam penelitian ini adalah biosorben tanpa modifikasi (BTM) dan 
bisorben terimpregnasi basa (BTB). Pada $\mathrm{BTB}$, digunakan $\mathrm{NaOH} 0,1 \mathrm{~N}$ sebagai basa dengan perbandingan 100 gram biosorben dalam 2 liter $\mathrm{NaOH}$ 0,1 N. Impregnasi oleh basa dilakukan untuk mengaktifkan biosorben sampai ke dalam pori bukan hanya terbatas pada permukaan. Impregnasi oleh basa juga bertujuan untuk menyingkirkan senyawa lignin yang terkandung dalam tkks. Menurut Nevvel dan Zerronian, 1985 dalam Darnoko, 1995 menyatakan bahwa lignin merupakan senyawa polimer aromatik komplek yang terbentuk melalui proses polimerisasi tiga dimensi dari sinapil alkohol yang merupakan turunan dari fenil propane. Adanya ikatan aril eter menyebabkan lignin mudah dihidrolisis oleh basa. Biosorben tanpa modifikasi berwarna coklat muda, sedangkan biosorben terimpregnasi basa berwarna coklat tua.

Biosorben tanpa modifikasi memiliki kadar air rata - rata 6,09\% sedangkan biosorben terimpregnasi basa memiliki kadar air rata - rata $8,01 \%$. Penentuan kadar air dilakukan karena akan berpengaruh dalam proses penyimpanan biosorben. Standar kadar air biosorben asal tkks belum ada, sehingga mengacu pada standar kadar air arang aktif yaitu sebesar $15 \%$. Kadar air yang diperoleh untuk biosorben tanpa modifikasi dan biosorben terimpregnasi basa hasilnya jauh lebih kecil. Kadar air dari sampel diharapkan mempunyai nilai rendah karena kadar air yang tinggi akan mengurangi daya jerap arang aktif terhadap gas maupun cairan gas (Pari, 1996).

\section{Panjang Gelombang Maksimum Fenol}

Hasil penetapan panjang gelombang maksimum fenol dengan alat spektrofotometer Vis Geneysis 20 diperoleh panjang gelombang maksimum adalah $454 \mathrm{~nm}$. Panjang gelombang ini digunakan untuk penentuan konsentrasi fenol selanjutnya. Kurva hasil penentuan panjang gelombang maksimum disajikan pada Gambar 2.

\section{Kondisi Optimum Adsorpsi Fenol oleh Biosorben}

Keadaan dimana kapasitas adsorpsi memberikan nilai maksimum merupakan keadaan proses adsorpsi dalam keadaan kesetimbangan. Dikatakan dalam keadaan setimbang karena laju sorpsi sama dengan desorpsi. Parameter yang dianalisis pada penentapan kondisi optimum adsorpsi fenol oleh BTM dan BTB terdiri atas waktu, bobot dan $\mathrm{pH}$ optimum.

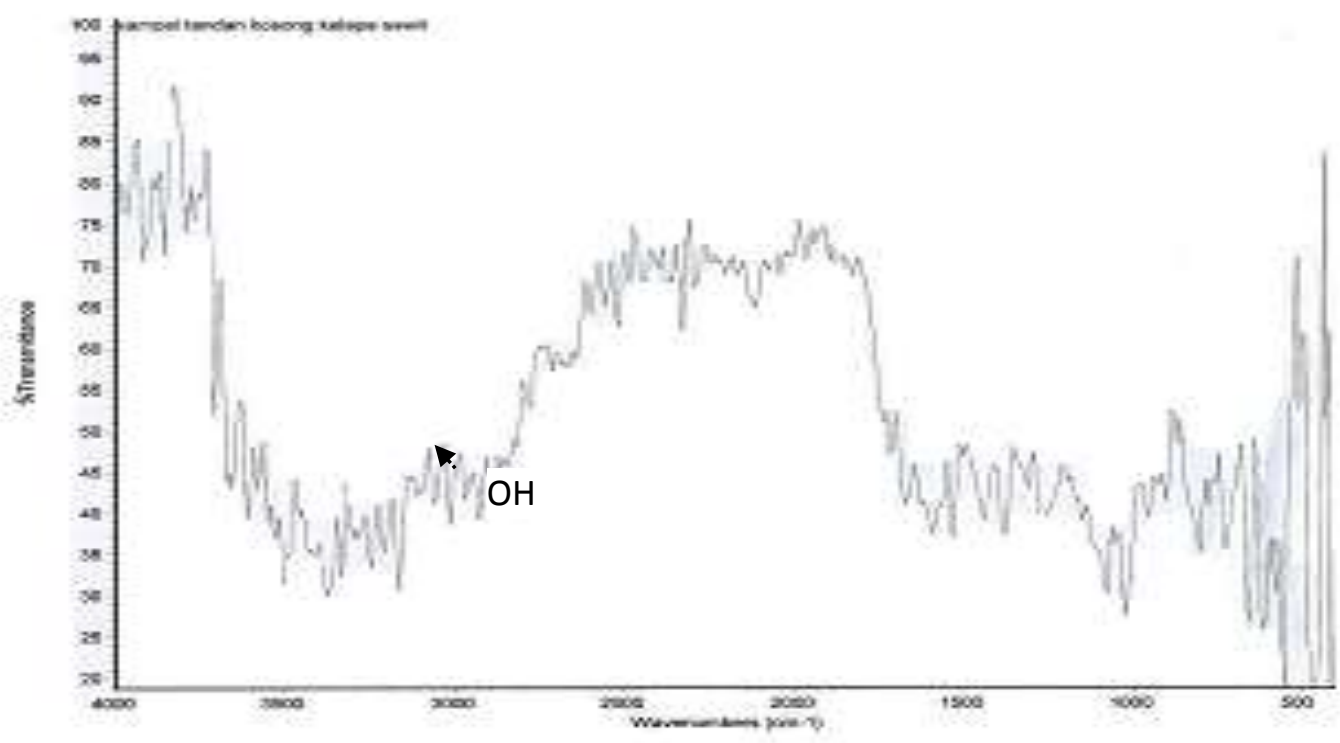

Gambar 1. Spektrum Infra Merah Biosorben TKKS 
1. Waktu Optimum Adsorpsi Fenol

$\begin{array}{ccr}\text { Lamanya proses } & \text { adsorpsi } \\ \text { ditentukan berdasarkan } & \text { kapasitas }\end{array}$
adsorpsinya selama rentang waktu tertentu. Saat kapasitas adsorpsi mencapai nilai maksimum, maka lamanya proses adsorpsi tersebut diambil sebagai waktu optimum adsorpsi. Hasil dari penetapan waktu adsorpsi optimum dengan kondisi pH 5,5 dan bobot biosorben 0,5 gram disajikan pada Gambar 3.

Berdasarkan Gambar 3, dapat dilihat bahwa proses adsorpsi fenol yang terjadi oleh BTM pada selang waktu 5-60 menit tidak mengikuti pola yang serupa. Hal ini disebabkan biosorben yang digunakan berasal dari bahan alam yang jumlah sisi aktifnya tidak sama dari setiap sampel dengan kata lain sampel biosorben yang digunakan tidak homogen dan proses adsorpsi yang terjadi tidak menggunakan metode batch atau continue, melainkan setiap ragam waktu dilakukan preparasi dari mulai tahap penimbangan biosorben. Dilihat dari segi matematikanya, data kapasitas adsorpsi dari rentang waktu 10 sampai 60 menit tidak berbeda nyata. Pada saat menit ke 120 menunjukkan kapasitas adsorpsi yang meningkat tajam dan setelah 120 menit yaitu pada menit ke 240 terjadi penurunan kapasitas adsorpsi. Adsorpsi fenol dengan menggunakan BTM optimum pada menit ke 120 untuk mencapai kapasitas adsorpsi maksimum yaitu sebesar 92,2457 ug/g biosorben. Sedangkan untuk adsorpsi fenol oleh BTB dapat terlihat pada gambar bahwa kapasitas adsorpsi naik dari rentang waktu 5 menit hingga 10 menit. Pada menit ke 10 dapat dilihat merupakan waktu optimum adsorpsi fenol oleh BTB. Terlihat dari Gambar 3, kapasitas adsorpsi menurun setelah menit ke 10.

Peningkatan kapasitas adsorpsi disebabkan oleh pembukaan tapak aktif yang lebih besar sehingga biosorben lebih banyak mengikat adsorbat. Setelah waktu optimum adsorpsi tercapai, kapasitas adsorpsi (Q) cenderung menurun yang disebabkan oleh jumlah biosorben yang berikatan dengan adsorbat sudah dalam keadaan jenuhnya, sehingga apabila ditambahkan waktu adsorpsi yang berlebih akan menyebabkan terjadinya proses desorpsi atau pelepasan kembali antara biosorben atau pelepasan kembali antara biosorben dan adsorbat.

\section{Bobot Optimum Adsorpsi Fenol oleh BTM dan BTB}

Pengaruh bobot biosorben terhadap kapasitas adsorpsi dapat dilihat pada Gambar 4. Hasil penelitian yang dilakukan dengan kondisi $\mathrm{pH}$ 5,5 dan waktu optimum, menunjukan adanya peningkatan kapasitas adsorpsi seiring dengan meningkatnya bobot biosorben.

Berdasarkan Gambar 4, terjadi kenaikan kapasitas adsorpsi dari 39,2575 $\mu \mathrm{g} / \mathrm{g}$ menjadi $81,8800 \mu \mathrm{g} / \mathrm{g}$ biosorben pada saat bobot BTM yang digunakan 0,5 - 1 gram, akan tetapi terjadi penurunan kapasitas adsorpsi ketika bobot biosorben mencapai 1,5 - 2 gram. Sehingga bobot optimum biosorpsi terjadi pada saat BTM 1 gram dengan kapasitas $81,8800 \mu \mathrm{g} / \mathrm{g}$ biosorben. Sedangkan pada BTB terjadi peningkatan kapasitas adsorpsi pada saat bobot biosorben 0,5 gram, setelah itu penambahan bobot tidak memberikan peningkatan kapasitas adsorpsi. Terjadi penurunan kapasitas adsorpsi setelah kapasitas adsorpsi mencapai optimum pada bobot 0,5 gram dengan kapasitas adsorpsi $525,0874 \mu \mathrm{g} / \mathrm{gram}$ untuk BTB.

Peningkatan adsorpsi disebabkan oleh jumlah pembukaan tapak aktif yang lebih besar sehingga biosorben lebih banyak menjerap adsorbat dan kapasitas adsorpsi akan meningkat sampai tercapainya bobot optimum. Setelah kondisi optimum, terjadi penurunan kapasitas adsorpsi disebabkan sudah tidak ada lagi adsorbat yang dijerap sehingga penambahan biosorben sampai kondisi tertentu tidak akan memberi dampak pada peningkatan kapasitas adsorpsinya dan akan menyebabkan terjadinya proses desorpsi. Hal ini sesuai yang dilakukan oleh Barros (2003) yang menyatakan bahwa pada saat ada peningkatan bobot adsorben, maka ada peningkatan persentase penjerapan dan penurunan kapasitas adsorpsi. 
Kapasitas adsorpsi dari bobot BTB cenderung menurun seiring dengan bertambahnya bobot biosorben yang ditambahkan. Hal ini disebabkan oleh jumlah biosorben yang berikatan dengan adsorbat sudah dalam keadaan jenuhnya sehingga apabila ditambahkan biosorben yang berlebih menyebabkan terjadinya proses desorpsi.

\section{Kondisi pH Optimum Adsorpsi Fenol}

Kapasitas adsorpsi dapat dipengaruhi oleh $\mathrm{pH}$ larutan yang diperlukan untuk keakuratan parameter adsorpsi (Jason, 2004). Kondisi pH berpengaruh pada sorpsi karena $\mathrm{pH}$ akan mempengaruhi sifat elektrokimia larutan dan muatan partikel atau biosorben. Hubungan antara $\mathrm{pH}$ dengan kapasitas adsorpsi disajikan pada Gambar 5.

Secara umum, meningkatnya kapasitas adsorpsi sejalan dengan meningkatnya $\mathrm{pH}$ hingga kisaran $\mathrm{pH}$ tertentu. Pada bisosorben tanpa modifikasi
(BTM) $\mathrm{pH}$ optimum dicapai pada $\mathrm{pH} 7$ dengan kapasitas adsorpsi 84,4081 $\mu \mathrm{g} / \mathrm{g}$ biosorben. $\mathrm{pH}$ optimum dicapai pada $\mathrm{pH} 7$ dikarenakan biosorben yang bersifat netral akan lebih cepat menjerap larutan fenol yang bermutan netral juga. Pada $\mathrm{pH} 3$ dan 5 larutan fenol dalam kondisi asam sehingga jumlah fenol yang terjerap dalam biosorben lebih sedikit dibanding pada $\mathrm{pH}$ netral. Pada pH 9 kapasitas adsorpsi fenol kembali berkurang hal ini juga disebabkan oleh hal yang serupa pada $\mathrm{pH} 9$ fenol bersifat basa sehingga fenol yang terjerap dalam biosorben berkurang. Dan terbentuknya ion Natrium fenolat menyebabkan terjadinya ikatan Hidrogen antara Fenol dengan sisi aktif biosorben menjadi berkurang (R. Subha dan C. Namasivayam, 2009). Hal ini sesuai dengan penelitian sebelumnya yang menyatakan bahwa $\mathrm{pH}$ optimum transport fenol oleh membran cair polyeugenol terjadi pada $\mathrm{pH}$ yang mendekati netral yaitu 6,8 (Maslahat \& Kiswandono, 2010).

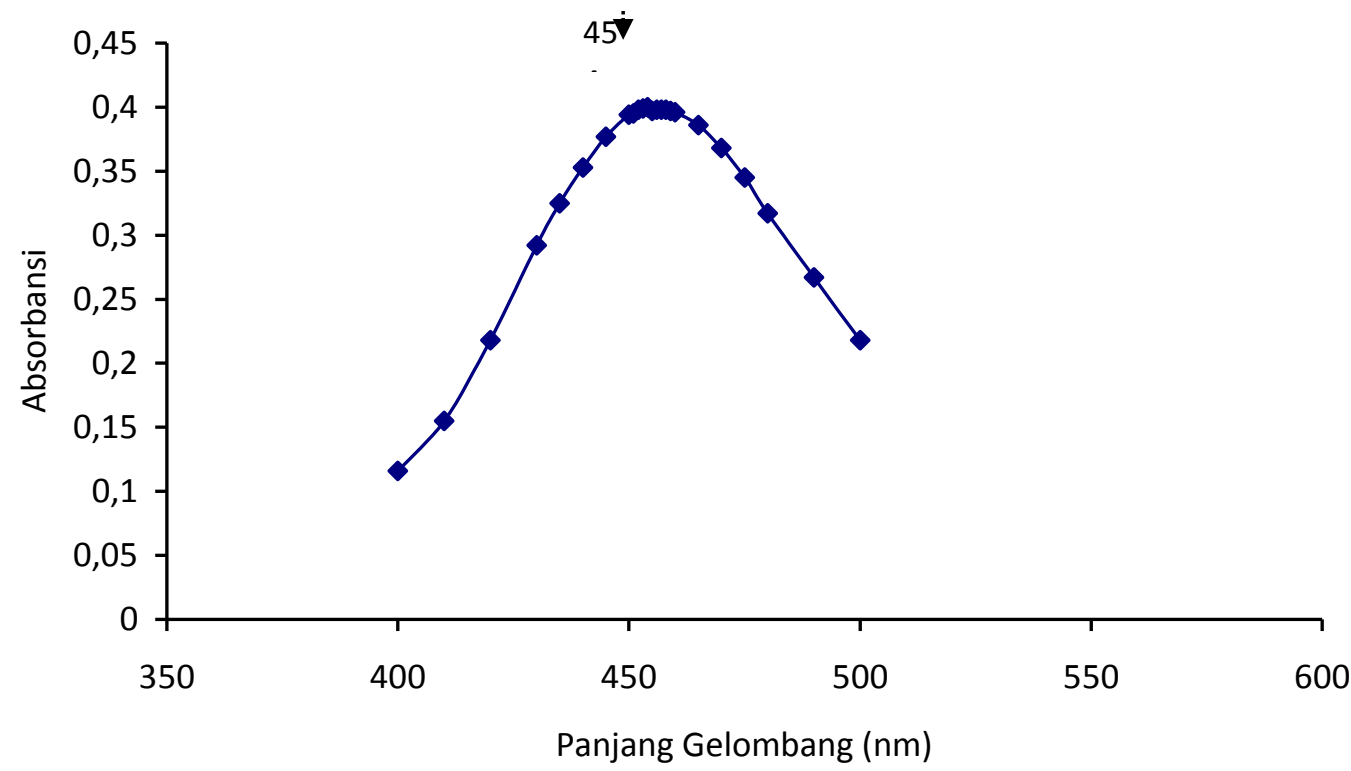

Gambar 2. Panjang Gelombang Maksimum Fenol 


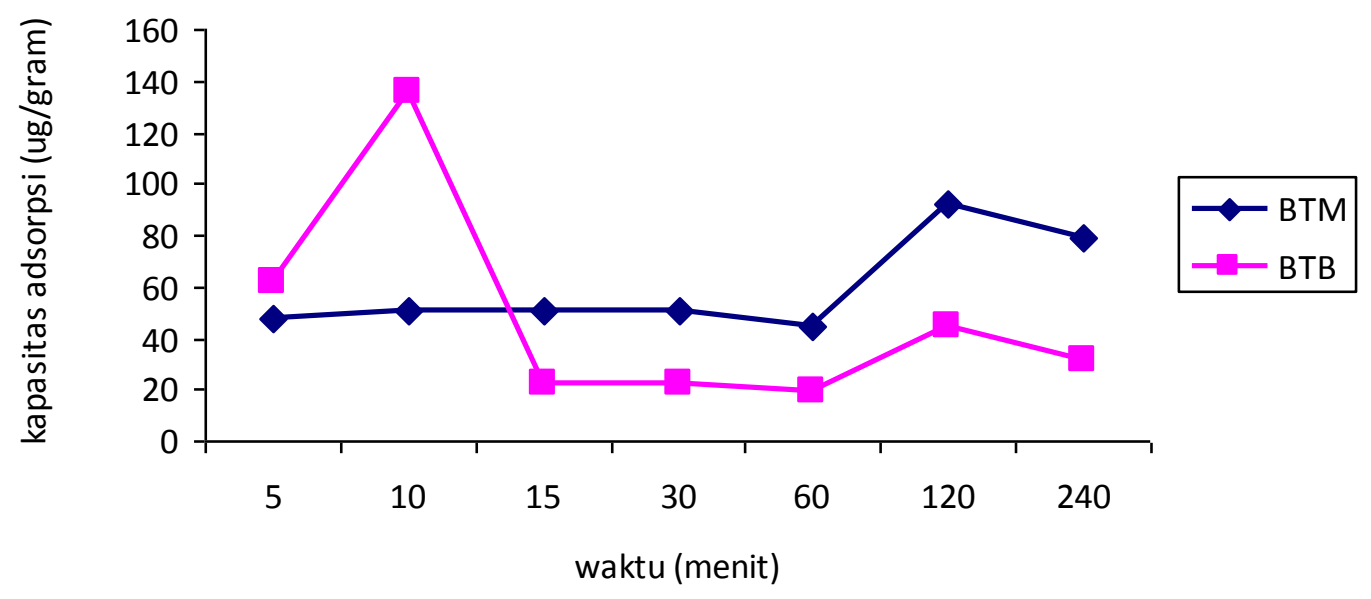

Gambar 3. Waktu Optimum Proses Sorpsi Fenol oleh BTM dan BTB

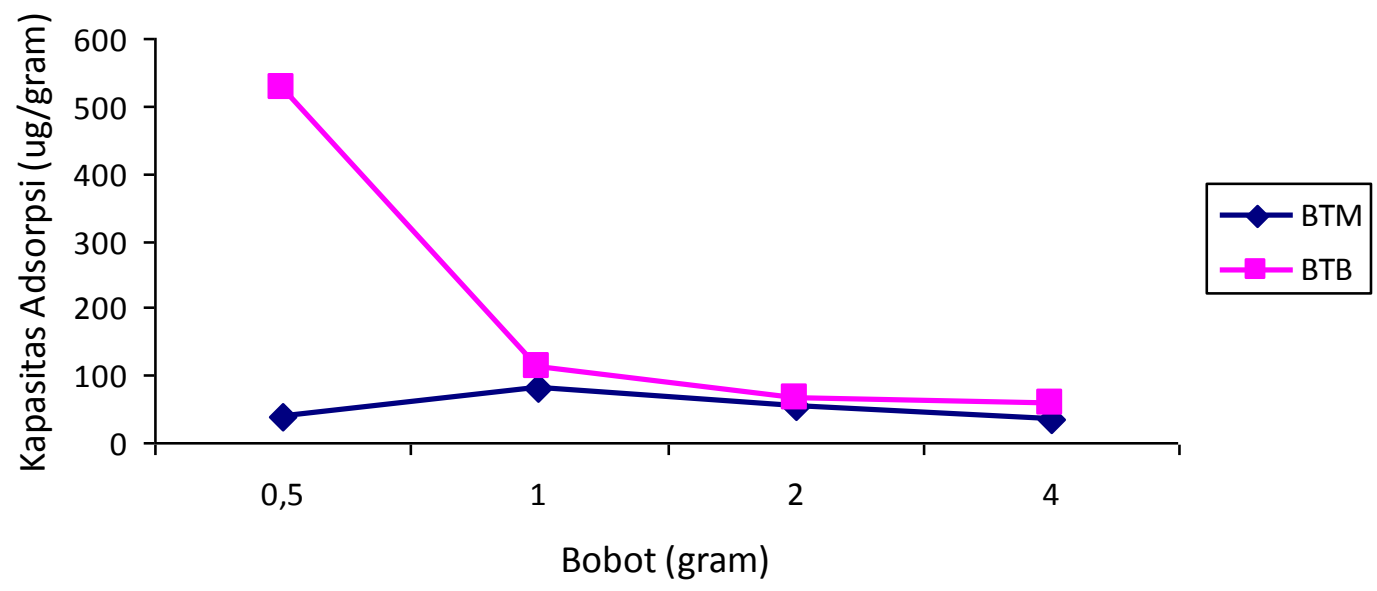

Gambar 4. Bobot Optimum Adsorpsi Fenol oleh BTM dan BTB

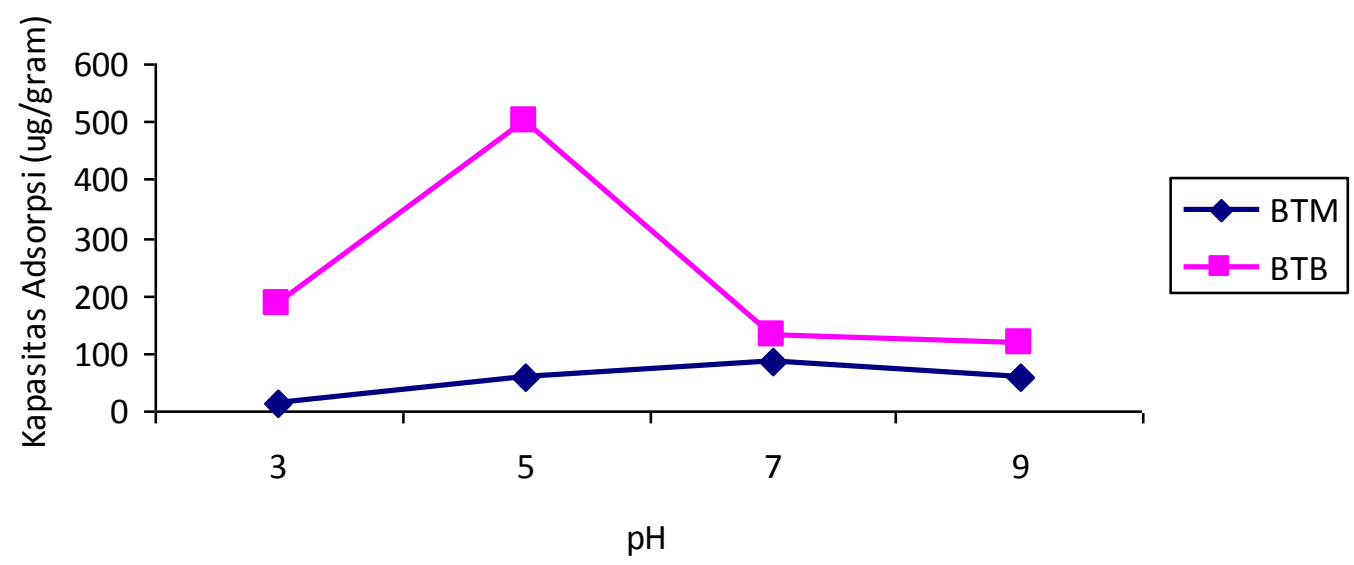

Gambar 5. Pengaruh pH pada Proses Adsorpsi Fenol oleh BTM dan BTB 
Berdasarkan hasil penelitian, kapasitas adsorpsi maksimum terjadi pada pH 5 dengan nilai kapasitas adsorpsi $502,724 \mu \mathrm{g} / \mathrm{g}$ biosorben (Gambar 5). Hasil dari kapasitas adsorpsi pada $\mathrm{pH} 5$ tidak berbeda jauh dari $\mathrm{pH}$ awal larutan yaitu 5,59 dengan kapasitas adsorpsi 525,0874 $\mu \mathrm{g} / \mathrm{g}$ biosorben. Hal ini dikarenakan biosorben yang sudah diimpregnasi oleh basa memiliki sifat basa dipermukaan sehingga akan lebih efektif proses penjerapan apabila fenol yang dijerap pun bersifat asam. Namun pada $\mathrm{pH} 3$ keberadaan ion $\mathrm{H}^{+}$semakin banyak, sehingga ion $\mathrm{H}^{+}$yang terlalu banyak ini dapat menghalangi proses penjerapan fenol oleh biosorben. Sedangkan untuk $\mathrm{pH}$ yang lebih tinggi yaitu pada $\mathrm{pH} 9$ dimana fenol dalam keadaan basa, proses penjerapan fenol akan mengalami penurunan hal ini dikarenakan terbentuknya natrium fenolat yang akan mengurangi ikatan hidrogen yang terjadi antara biosorben dan fenol.

\section{Isoterm Adsorpsi}

Tipe isoterm adsorpsi dapat digunakan untuk mempelajari mekanisme penjerapan. Adsorpsi fase padat-cair pada umumnya mengacu pada tipe isotherm Freundlich dan Langmuir (Atkins, 1999). Biosorben tandan kosong kelapa sawit tanpa modifikasi memberikan linearitas 99,59\% untuk isotherm Langmuir (Gambar 6) dan $99,36 \%$ untuk isotherm Freundlich (Gambar 7). Biosorben tandan kosong kelapa sawit terimpregnasi basa memberikan linearitas $99,91 \%$ untuk isoterm Langmuir (Gambar 8), dan 99,84\% untuk isotherm Freundlich (Gambar 9). Adsorpsi fenol oleh biosorben tkks tanpa modifikasi dan biosorben tkks terimpregnasi basa mengikuti persamaan isoterm Langmuir karena linearitas untuk tipe isoterm Langmuir lebih besar.

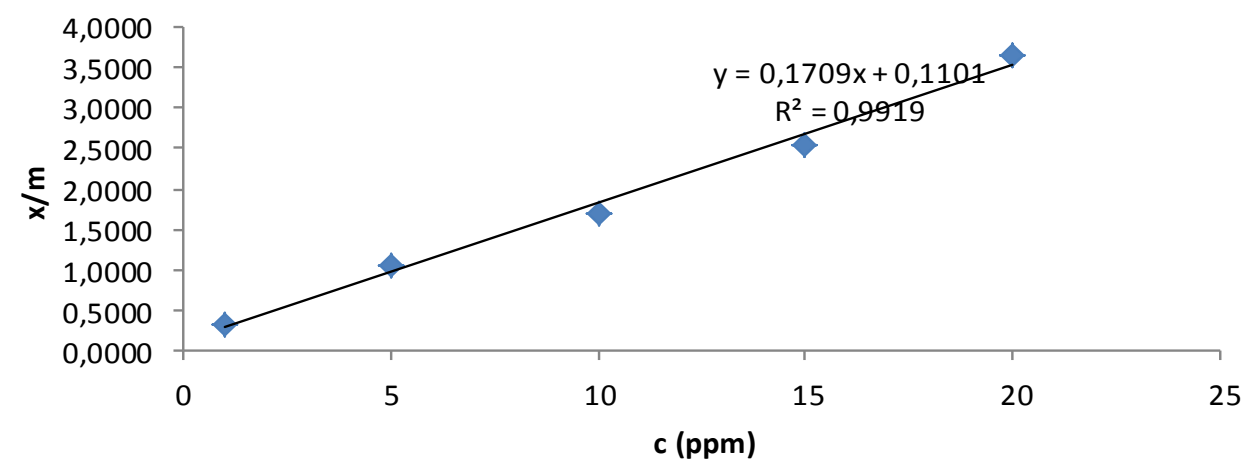

Gambar 6. Isoterm Langmuir Adsorpsi Fenol oleh Biosorben Tanpa Modifikasi

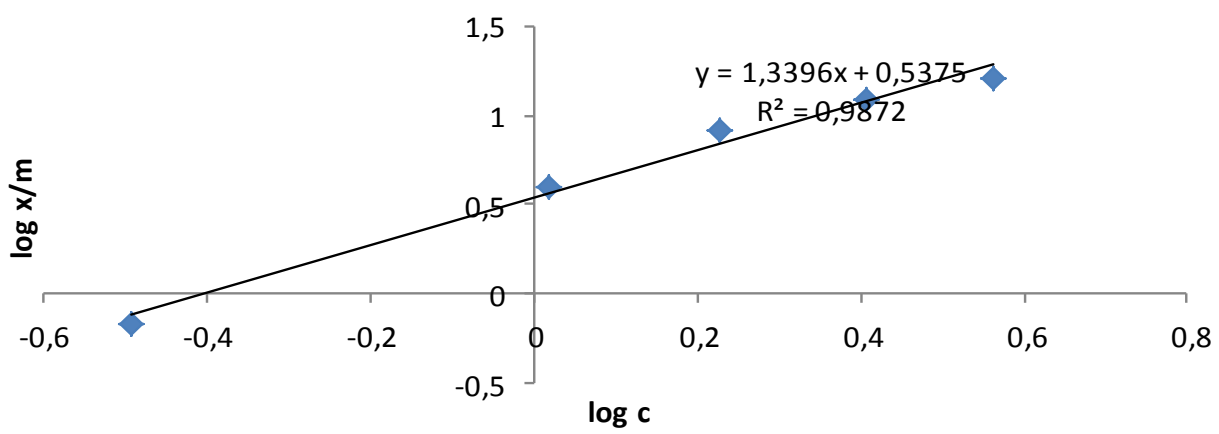

Gambar 7. Isoterm Freundlich Adsorpsi Fenol oleh Biosorben Tanpa Modifikasi 


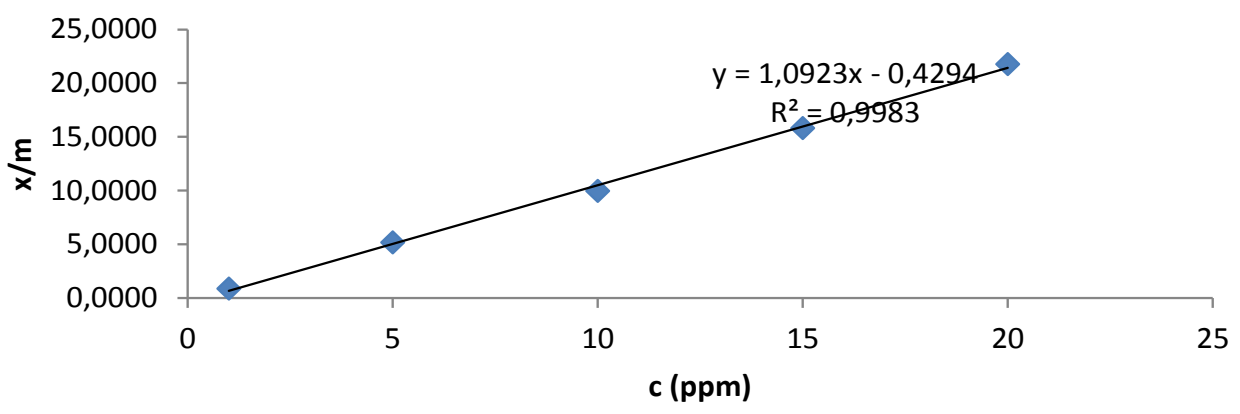

Gambar 8. Isoterm Langmuir Adsorpsi Fenol oleh Biosorben Terimpregnasi Basa

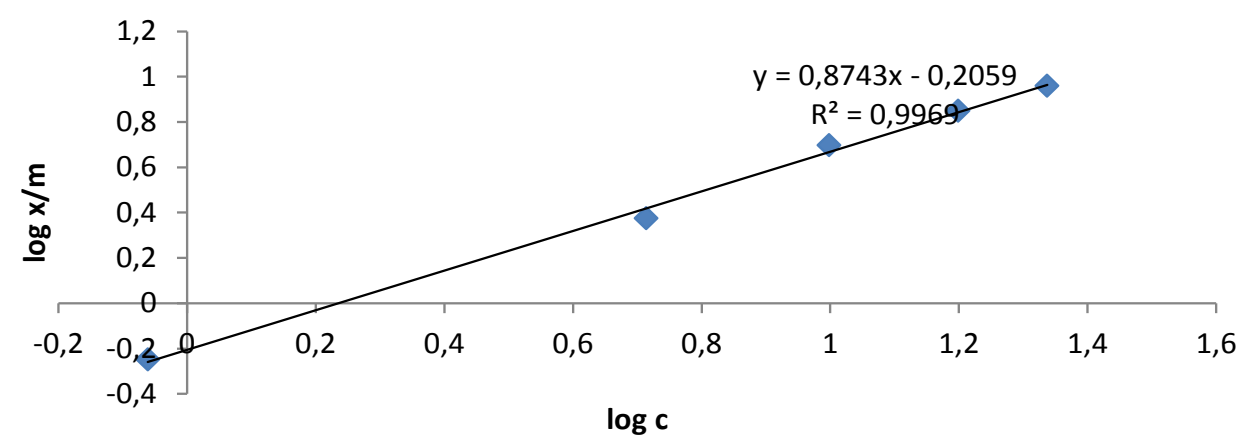

Gambar 9. Isoterm Freundlich Adsorpsi Fenol oleh Biosorben Terimpregnasi Basa

Proses adsorpsi fenol oleh kedua biosorben mengikuti persamaan isoterm Langmuir, sehingga bisa diasumsikan bahwa fase biosorben membentuk lapisan monolayer, keadaan setimbang bila kecepatan adsorpsi sama dengan kecepatan desorpsi, permukaam fase adsorbat bersifat homogen, dan fase adsorbat merupakan zat yang homogen (Anggraningrum 1996). Adsorpsi dapat berlangsung menurut isoterm Freundlich dan isoterm Langmuir sekaligus. Hal ini dapat diketahui jika linieritas kurva untuk kedua isoterm tinggi.

Nilai Konstanta $\mathrm{n}, \mathrm{k}, \alpha$, dan $\beta$ dapat dihitung dari persamaan Langmuir dan Freundlich yang di dapat dan disajikan pada Tabel 1 dan Tabel 2.

Nilai konstanta $\mathrm{k}, \alpha, \mathrm{n}, \beta$ dan yang diperoleh dari persamaan regresi Langmuir dan Freundlich menggambarkan besaran nilai adsorbat yang dapat diadsorpsi pada sisi permukaan biosorben. Nilai $k$ menunjukkan kemampuan proses adsorpsi dan $\mathrm{n}$ menunjukkan konsentrasi adsorpsi, semakin naik nilai ini maka akan semakin besar proses adsorpsi.

\section{KESIMPULAN}

Tandan kosong kelapa sawit dapat digunakan sebagai biosorben fenol. Kondisi optimum BTM pada waktu adsorpsi 120 menit, bobot biosorben 1 gram, dan $\mathrm{pH}$ 7. Kondisi optimum BTB adalah waktu adsorpsi 10 menit, bobot biosorben 0,5 gram, dan $\mathrm{pH}$ 5. Kapasitas adsorpsi (Q) pada kondisi optimum BTM dan BTB berturut-turut adalah 84,4081 dan $502,724 \mu \mathrm{g} / \mathrm{g}$ biosorben. Adsorpsi larutan fenol oleh BTM dan BTB mengikuti persamaan isoterm Langmuir. Dari hasil penelitian dapat dilihat bahwa kapasitas adsorpsi fenol oleh biosorben tkks yang terimpregnasi basa memberikan hasil yang lebih besar. 
Table 1. Nilai Konstanta $\mathrm{n}$ dan k dari Persamaan Freundlich

\begin{tabular}{llll}
\hline Biosorben & $n$ & $k$ & $\mathrm{R}$ \\
\hline BTM & 0,7465 & 3,4475 & 99,36 \\
BTB & 1,1437 & 1,6065 & 99,84 \\
\hline
\end{tabular}

Tabel2. Nilai Konstanta $\alpha$ dan $\beta$ dari Persamaan Langmuir

\begin{tabular}{llll}
\hline Biosorben & $\alpha$ & $\beta$ & $\mathrm{R}$ \\
\hline BTM & 5,8514 & 1.5522 & 99,59 \\
BTB & 0.9155 & $-0,3930$ & 99,91 \\
\hline
\end{tabular}

\section{DAFTAR PUSTAKA}

Ahalya N. T.V., Ramachandra, R. D., Kanamadi, 2004. Biosorption of Heavy Metals. Centre for Ecological Science., Indian Institute of Science. Bangalore, India.

Alva, V. A dan B. M. Peyton, 2003. Phenol and Catechol Biodegradation by the aloalkaliphile Halomonas campisalis: Influence of $\mathrm{pH}$ and Salinity.

Anggaraningrum, IT, 1996. Model Adsorpsi Ion Kompleks Koordinasi Nikel (II) pada Permukaan Alumina. Tesis. Magister Sains Ilmu Kimia. Universitas Indonesia. Depok.

Atkins, P. W., 1999. Kimia Fisik Jilid 1. Irma I Kartohadiprojo, penerjemah; Rohadyan $\mathrm{T}$, Hadiyana K, editor. Erlangga. Jakarta. Terjemahan dari Physical Chemistry.

Bird T., 1993. Kimia Fisik untuk Universitas. Gramedia Pustaka Utama. Jakarta.
Castelan, GV., 1982. Physical Chemistry. Ed. Ke-3. General Graphic Services. Jakarta.

Darnoko, P., Guritno A, Sugiharto, Sugesty. 1995. Pembuatan Pulp dari Tandan Kosong Sawit dengan Penambahan Surfaktan. Jurnal Penelitian Kelapa Sawit 3 (1): 75 87.

David, A. R., 2000. Characterization of Pecan Shell-based Carbon. Technical Completion [Laporan]. New Mexico State University. New Mexico.

Day, R. A. JR., dan A. L Underwood, 2002. Analisis Kimia Kuantitatif Edisi Keenam. Erlangga. Jakarta.

Ditjen PPHP,. 2006. Pedoman Pengolahan Limbah Industri Kelapa Sawit. Departemen Pertanian. Jakarta.

Fessenden R. J dan J. S Fessenden, 1986. Kimia Organik Ed. Ke-3. Aloysius Hadyana Pudjaatmaka Ph.D., penerjemah; Penerbit Erlangga. Terjemahan dari Organic Chemistry, Third Edition. 
Gufta, F. K. ,1998. Utilization of Bagasse Fly Ash Generated in The Sugar Industry for Removal and Recovery of Phenol and $p$ Nitrophenol from Wastewater. J Chem Technol Biotechnol 70: 180186.

Jason, P. P., 2004. Activated carbon and some applications for the remediation soil and ground water pollution.

http//www.cee.edu/program areas diakses pada 8 Juni 2004.

Lynch, C. T., 1990. Practical Handbook ofMaterial science. Ed ke-2.CRC Pr.New York.

Maslahat, M., dan A. Kiswandono, 2010. Studi Transport Senyawa Fenol Menggunakan Membran Cair Polieugenol dengan Pelarut Diklorometana. Laporan Penelitian Dosen Muda Dikti. Universitas Nusa Bangsa. Bogor.

Marshall W. E., dan M. J. Mitchell, 1996. Agriculture by-Product as Metal Adsorbent : Sorption Properties and Resistance to Mechanical Abrasion. J Chem Tehnol Biotechnol 66 : 192 - 198.

Mortaheb H. R, M. H. Amini, F. Sadeghian, B. Mokhtarani, H. Daneshyar. Study on a new surfactant for removal of phenol from wastewater by emulsion liquid membran. Journal of Hazardous Materials 2008; 160: 582-588.

Mulder. M. 1996. Basic Principles of Membran Technology. Sec. edition. Kluwer Academic Publisher. Netherland.

Naibaho, Ponten M. 1998. Teknologi Pengolahan Kelapa Sawit. Pusat Penelitian Kelapa Sawit. Medan.
Nur, M. A. 1989. Bahan Pengajaran : Spektroskopi. Institut Pertanian Bogor. Bogor.

Osjick, J dan I. L. Cooper. 1994. Adsorption. Ellis Horwood Publisher,Ltd. Chichester.

Pahan, I. 2010. Panduan Lengkap Kelapa Sawit Manajemen Agribisnis dari Hulu hingga Hilir. Penebar Swadaya. Jakarta.

Pamin, K dan Darnoko. 1999. Prospek Industri Dengan Bahan Baku Limbah Padat Kelapa Sawit di Indonesia. Buletin. PPKS 2: 203209.

Setiadi, E. S. 1999. Pengaruh Impregnan $\mathrm{NaOH}$ Terhadap Luasan Permukaan Karbon Aktif dan Kemampuan Adsorpsi Terhadap $\mathrm{CO}_{2}$. Fund Apl Kim A 17 : 1-7

Setiawan H. A, WIloso, EI, Soleha V, Barliati IF, Anggraeni. 2003. Peningkatan Kemampuan Daya Serap Sorben Serbuk Gergaji Kayu Albizia dengan Pengsulfonasi dan Pengujiannya dengan Zat Warna Tekstil Kationik. Alcheny vol $3 \mathrm{Hal}$ 10-15.

Subha, R dan C. Namasivayam. 2009. Kinetics and Isotherm Studies for The Adsorption of Phenol Using Low Cost Micro Porous $\mathrm{ZnCl}_{2}$ Activated Coir Pith Carbon. Can. J. Civ. Vol 36. Hal 148-159. NRC Research Press. Inggris.

Stumm, W. dan J. J. Morgan, 1996. Aquatic Chemistry, Chemical Equilibria and Rates in Natural Waters, 3rd ed. John Wiley \& Sons, Inc., New York, 1022p.

Vimal C. Srivastava, Mahadeva M. Swamy, Indra D. Mall, Bashaswar Prasad, and Indra M. Mishra. 2005. "Adsorptive removal of phenol by baggase fly ash and 
activated carbon : Equilibrium, kinetics and thermodynamics" Colloids and Surface area A : Physicochem.Eng Aspect vol 272 p.89-104.
Volesky B. 2004. Biosorption. Biological and Environmental System group. Mc Gill University. Canada.

Watts, R. J. 1998. Hazardous Wastes : Sources, Pathways, Receptors. John Willey and Sons. New York. 